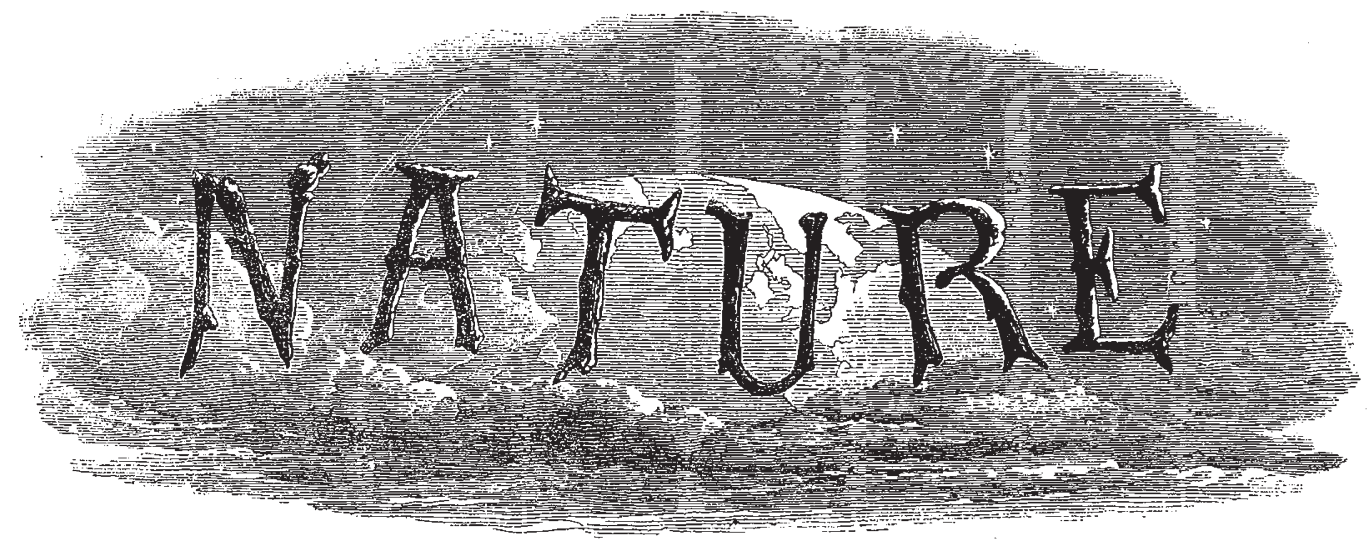

A WEEKLY ILLUSTRATED JOURNAL OF SCIENCE

"To the solid ground

of Nature triksts the nizd which builds for aye."-WORDsworTH

THURSDAY, NOVEMBER 6, 1873

\section{THE GOVERNIIENT AND OUR NATIONAL MUSEUMS}

WE referred last week to the intestion of the Govern$W$ ment to transfer one of the Metropolitan Museums under the control of a responsible Minister of the Crown, to the fifty irresponsible Trustees of the British Museum, this step being contemplated without referring the question either for the opinion of the Science Commission, now inquiring into these subjects, or for the authority of Parliament. We have learnt since that the measures for effecting this change are in active progress. Lord Ripon and the Trustees of the British Museum having agreed that the transfer was to be made if practicable, Sir Francis Sandford, Mr. MacLeod, and Major Donnelly, on behalf of the Science and Art Department; and Messrs. Winter Jones, Franks and Newton, on behalif of the Trustees of the British Museum; are now busy as Commissioners to find out if the transfer be practicable, and they have been exploring the South Kensington Museum for this purpose during the last week, taling notes of its contents, inspecting its refreshment rooms, its waiting rooms and the like.

What the Commissioners will propose as practicable is of course known only to themselves, if it be known even to them. Thus much, however, is known: the South Kensington Museum must remain the head-quarters of Science and Art Teaching, unless that too is to be put under the Archbishop of Canterbury and his co-Trustees, and if not, then there must be a dual Government in one and the same building, unless Mr. Lowe's project be abandoned. Now the dual Government means that one officer will represent the Archbishop of Canterbury and his co-forty-nine trustees in the Museum, and another the Lord President of the Councii. The officer representing the Department will take orders from the Lord President. The officer representing the Trustees must from time to time go to Mr. Winter Jones to ascertain what the fifty Trustees have decided, and to receive his instructions how their decision is to be interpreted. Mr. Winter
Jones' labours, already said to be ill-remunerated, will be increased, and his well-krown powers of organisation sorely taxed. If there be two things which nature puts in ferocious antagenism one to another, it is two public officers under different responsibilities. No envy, hatred, or malice like that between two public officers. How every officer adores the Treasury! how the Audit Office loves the Treasury! what models of civil Letters the Treasury always writes to the Officer of Works, - and so on.

The public has had already a specimen of this kind of dual Government at the South Kensington Museum, which has had disastrous results for Science. When the "Boilers" were first erected in 1856 , the Commissioners of Patents had assigned to them a portion at the south end of the building for exhibiting those Mechanical and Scientific objects, which under a fiction were supposed to have derived their origin in "Patents." It was necessary that the visitors to all parts of the "Boilers" and to the Picture Galleries should pass through the "Patent Division." The Lord President made sensible rules for admitting the public on three days, open from io A.M. to ro P.M., and three days called "Students' days," when persons not students paid sixpence each, or ten shillings a year, the object being to have three days free from crowds and kept quiet for study. After a while the Commissioners of Patents were scandalised at thus receiving public money (they are the instruments for taking seventy thousand a year from Inventors and misapplying it to General Taxation) and they said they preferred crowds every day as the most convenient public arrangement. The authorities came to open discord on the point, and the matter could only be resolved by separating the "Patent" from the other collections. So the Patent Commissioners built a separate entrance for themselves. What has been the result? About eight millions of visitors to the South Kensington Museum who would otherwise have seen the "Patent Museum" have not done so, and the Commissioners have deprived themselves and their museum of the moral support of these great numbers. And what has been the result of this? The Chancellor of the Exchequer has been allowed 
to sack more than a million of pounds sterling realised from the taxes imposed on inventors' patent fees, and has not allowed one farthing to be spent for the provision of a suitable building for the "Patent Museum." Anything more discreditable to the nation than the building now crowded with models cannot be conceived. Many of the passages are not eighteen inches wide! What the present Lord Chancellor, the head Patent Commissioner, would say if he were ever to see it, cannot easily be imagined. We advise his Lordship to hold a Board in the building as soon as possible. It will probably be the first Board of Patent Trustees that ever sat there. We are satisfied that the result would be that he would instantly cause the present exhibition to be closed, and adequate space found elsewhere. Then what have inventors got in return for the tax of a million drawn from them? And what may not invention have lost by this indefensible principle of taxation?

Here then is already a very practical illustration of dual government in the South Kensington Museum already; one part of that government beincr composed of Trustees, who, it is reported traditionally, have never once met as a Board in their own Museum to see what was imposed upon a suffering public, upon their responsibility. We do not believe such a state of things would have been suffered under South Kensington administration. Mr. Lowe, when Vice-President, of the Council would not have suffered it.

The indifference of the British Museum Trustees to some of the best interests of Science in their own museum has been denounced again and again by commissions and committees, who report and report, but make no impression on a corporation of fifty trustees. That alone is a reason why they should not be allowed to meddle with South Kensington.

Although, as we have stated, this proposalwas madewithout reference either to the opinion of those to whom the interests of Science and Art are more precious than they are to the members of the present Government, or to the opinion of the House of Commons, we learn that Mr. Mundella has cxtracted a promise from Mr. Gladstone that nothing shall be decided until Parliament meets again. Mr. Gladstone is perhaps surprised that there is any public interest in the subject. In the meantime, to assist him to form a correct judgment, we advise every learned society, which takes any branch of Science under its care, to memorialise the Prime Minister, and point out the crying necessity of a Minister, who shall be responsible to Parliament for Science, among other matters, and for all museums; that to transfor a museum already so represented to irresponsible trustees is a step worthy of the Middle Ages ; and finally, that while the South Kensington system represents everything that is best in the way of progress, so much, to say the least, cannot be urged in favour of the present management of the British Museum.

We can well understand the reason for the proposed change. It lies in the individual responsibility of a Minister and the energetic executive management which have raised in a few years the South Kensington Museum into an institution of which the nation has the greatest reason to be proud; which has made it the centre of the chief intellectual activity of the country, which has utilised its resources for the tcaching of hundreds of thousands of our teeming populations. The British Museum Trustees have done none of these things; they have given no trotble; they have borne snubbing admirably when they have moved, which has not been often. They have, in fact, proved an admirable buffer between subordinates anxious for progress and the Government; and, further, they have not been represented in the Cabinet. The moral which the Government has drawn from these facts is, that the South Kensington energy should have such a buffer, and in the existing members of the British Museum have found one ready to their hand. Hence the proposal which, if we mistake not, will, when it is generally known, not find a single supporter out of the Cabinet. It is quite possible that already it finds not many supporters in it.

\section{BAIN'S REVIEW OF "DARWIN ON EX. PRESSION"}

Revieqs of "Darwin on Expression." Being a Postscript to "The Senses and the Intellect." By Alexander Bain, LL.D., Professor of Logic in the University of Aberdeen. (Longmans, Green, and Co.)

THERE is nothing in this Postscript to "The Senses and the Intellect" so important to psychology as the declaration and announcement contained in the following sentences: "In the present volume I have not made use of the principle of Evolution to explain either the complex Feelings or the complex Intellectual powers. I believe, however, that there is much to be said in behalf of the principle for both applications. In the third edition of 'The Emotions and the Will,' now in preparation, I intend to discuss it at full length." No man can claim to have done more for the study of psychology than Prof. Bain; and in now recognising the principle of evolution and in incorporating it with his system, he is doing the science the greatest possible service. This is more than in some quarters was ever hoped from Prof. Bain, and more than was ever feared by those of his disciples who- after the manner of disciples-have clung most tenaciously to the defects of his system.

Though accepting the principle of evolution, Prof. Bain does not, it would seem, always look at phenomena from the evolutionist's point of view, as we understand it. Thus, in speaking of the large extent to which Mr. Darwin uses the principle of inheritance to account for the phenomena of expression, he says :- "Wielding an instrument of such flexibility and range as the inheritance of acquired powers, a theorist can afford to dispense with the exhaustive consideration of what may be due to the primitive mechanism of the system; he is even tempted to slight the primitive capabilities, just as the disbeliever in evolution is apt to stretch a point in favour of these original capabilities." But whence the so-called "primitive mechanism" which is here made separate and distinct from, set over against the products of inheritance? is not the "primitive me chanism" the "original capabilities" of every creature the res ults of evolution?

Mr. Darwin is accused of not having given sufficient attention to "spontaneity of movements," which, according to Prof. Bain, "is a great fact of the constitution." Now it may be that a "readiness to pass into movement, in the absence of all stimulation wh atever," is a fact of the constitution; but we fail to see that Prof. Bain has 